\title{
Penilaian aliran limbah elektronika di DKI Jakarta menggunakan Material Flow Analysis (MFA)
}

\author{
Dino Rimantho ${ }^{1}$, Erliza Noor ${ }^{2}$, Eriyatno ${ }^{3}$ dan Hefni Efendi ${ }^{4}$
}

1Mahasiswa Program Doktoral, Pengelolaan Sumberdaya Alam dan Lingkungan, Institut Pertanian Bogor: e-mail: dino.rimantho@univpancasila.ac.id

2Depatemen Teknologi Industri Pertanian, Institut Pertanian Bogor

${ }^{3}$ Research Center for Agriculture and Village, Institut Pertanian Bogor

${ }^{4}$ Pusat Penelitian Lingkungan (PPLH), Institut Pertanian Bogor, Institut Pertanian Bogor

\begin{abstract}
ABSTRAK
Peralatan elektronik diproduksi untuk memenuhi kebutuhan manusia, sehingga ini akan memiliki dampak signifikan terhadap peningkatan volume limbah elektronika di tempat pembuangan sampah di hampir semua negara. Salah satu masalah pencemaran lingkungan yang menjadi perhatian di seluruh dunia adalah pengelolaan limbah elektronik (ewaste). Ini karena peningkatan pesat dalam penggunaan produk elektronik. Dengan demikian, keberadaan peralatan listrik dan elektronik menjadi lebih pendek dan menjadi usang. Ketiadaan informasi terkait volume pembangkitan sampah dan aliran material merupakan salah satu masalah pemerintah Indonesia dalam mengelola e-waste. Oleh karena itu, tujuan dari makalah ini adalah untuk menghitung e-waste dan menganalisis aliran material. Metode yang digunakan dalam penelitian ini adalah Material Flow Analysis (MFA). Selanjutnya, survei responden rumah tangga dan sektor informal digunakan dalam penelitian ini. Kuesioner yang diadopsi dari UNEP dimodifikasi dan didistribusikan ke 400 rumah tangga dan 54 sektor informal di DKI Jakarta. Hasilnya menunjukkan tingkat total produksi e-waste yang dihasilkan sekitar 7713,42013 kg / tahun. Selain itu, perlu dikembangkan beberapa strategi seperti Extended Producer Responsibility (EPR) dan penempatan Dropbox pada tiap wilayah untuk menghindari dampak negatif. Penelitian ini dapat berupa informasi dalam mengisi keterbatasan data dan pengelolaan e-waste yang berkelanjutan di DKI Jakarta.
\end{abstract}

Kata kunci: DKI Jakarta, Limbah elektronika, pencemaran, MFA, UNEP

\begin{abstract}
Electronic equipment is produced to meet human needs, so this will also have a significant impact on increasing the rate of e-waste generation in landfills in almost all countries. One of the environmental pollution issues that are of concern throughout the world is the management of e-waste (e-waste). This is due to the rapid increase in the use of electronic products. Thus, the existence of electrical and electronic equipment becomes shorter and becomes obsolete. The absence of information related to the volume of e-waste generation and material flow is one of the problems of the Indonesian government in managing e-waste. Therefore, the purpose of this paper is to calculate e-waste and analyze material flow. The method used in this study is Material Flow Analysis (MFA). Furthermore, a survey of household and informal sector respondents was used. The questionnaire adopted from UNEP was modified and distributed to 400 households and 54 informal sectors in DKI Jakarta. The results show the total rate of generation of e-waste produced approximately $7713.42013 \mathrm{~kg} /$ year. Furthermore, it is necessary to develop several strategies such as Extended Producer Responsibility (EPR) and Dropbox placement in each districtin order to avoid negative impact. This research can be information in filling the data limitations and management of sustainable e-waste in DKI Jakarta.
\end{abstract}

Keywords: DKI Jakarta, E-waste, pollution, MFA, UNEP

Citation: Rimantho, D., Noor, E., Eriyatno, dan Efendi, H. (2019). Penilaian aliran limbah elektronika di DKI Jakarta menggunakan Material Flow Analysis (MFA). Jurnal Ilmu Lingkungan, 17(1),120-129, doi:10.14710/jil.17.1.120-129

\section{Latar Belakang}

Salah satu masalah pencemaran lingkungan yang menjadi perhatian di seluruh dunia adalah pengelolaan limbah elektronik. Hal ini disebabkan terjadinya peningkatan pesat dalam penggunaan produk elektronik. Inovasi teknologi yang sangat cepat dan penggantian peralatan analog merupakan salah satu penyebab tingginya tingkat produk elektronik yang menjadi limbah (Kiddee et al., 2013). Selain itu, orang membeli produk elektronik yang ditawarkan oleh penjual karena harganya yang terjangkau. Harga produk elektronik murah memainkan peran penting dalam meningkatkan laju timbulan 
sampah (Shah dan Batool 2015). Perangkat elektronik sangat sulit dipisahkan dari kehidupan orang-orang. Selain itu, keberadaan peralatan listrik dan elektronik menjadi lebih pendek dan menjadi usang. Oleh karena itu, semakin tinggi peralatan elektronik yang diproduksi untuk memenuhi kebutuhan manusia akan memiliki dampak yang signifikan terhadap peningkatan laju limbah elektronika di tempat pembuangan sampah di hampir semua negara.

Studi yang dilakukan oleh Sinha (2010) mencatat bahwa produk ITC yang menjadi limbah elektronika mencapai 53 juta ton. Selanjutnya, sebuah penelitian yang dilakukan oleh Sepúlveda et al., (2010) melaporkan bahwa limbah elektronika mencapai 40 juta ton per tahun secara global. Uni Eropa melaporkan bahwa tingkat pembuangan limbah elektronika pada tahun 2010 adalah sekitar 8,9 ton (Zoeteman et al. 2010). Jumlah limbah diperkirakan akan terus meningkat setidaknya 3-5\% per tahun, dan menjadi aliran limbah yang paling cepat berkembang di dunia industri (UNEP 2006). Umumnya, diperkirakan bahwa laju pembangkitan sampah elektronik adalah sekitar 40 juta ton per tahun (Schluep et al., 2009). Studi yang dilakukan terkait dengan laju timbulan sampah di beberapa negara di Asia seperti Taiwan, Cina, Thailand, Filipina, Korea, dan India menunjukkan peningkatan jumlah tingkat pembangkitan limbah elektronik (Yang et al., 2004; Terazono et al., 2006).

Pengelolaan limbah elektronika di Indonesia belum memiliki regulasi khusus. Dengan demikian, hal ini memiliki potensi untuk memunculkan masalah yang sangat kompleks seperti laju timbulan yang dipengaruhi oleh berbagai faktor seperti tingkat pendidikan, gaya hidup, tingkat pendapatan. Jadi, untuk membantu mengembangkan pengelolaan dengan benar. Sehingga perlu untuk mengidentifikasi, mengkarakterisasi dan mengalirkan material limbah secara rinci. Dengan demikian akan dapat membantu pemangku kepentingan yang terkait untuk mengetahui siapa saja pihak yang terlibat dalam "munculnya" limbah, untuk memprediksi dampak lingkungan dan menyelaraskannya dengan strategi penanganan yang efektif. Dari sudut pandang ini, dipandang perlu untuk mengetahui aliran limbah elektronika di DKI Jakarta. Selain itu, dapat mengidentifikasi dan menganalisis potensi pengelolaan e-waste yang berkelanjutan.

Dalam studi ini, akan dipetakan aliran dan penentuan tingkat laju timbulan limbah elektronika di DKI Jakarta. Untuk dapat menganalisa laju limbah elektronika dari rumah tangga akan menggunakan analisa aliran material (MFA). Brunner dan Rechberger, (2004) menjelaskan bahwa MFA adalah metode yang cocok untuk mendukung pengambilan keputusan dalam pengelolaan limbah dan sumber daya. Beberapa penelitian yang telah dilakukan sebelumnya terkait dengan penggunaan metode MFA dalam analisis laju timbulan limbah (Duygan dan Meylan, 2015; Kalmykova et al., 2015; Zeng et al., 2015). Selanjutnya, penerapan metode MFA dalam beberapa penelitian tentang limbah elektronik teknologi informasi (Nnorom dan Osibanjo, 2008; Yoshida et al., 2009). Selain itu, Muller et al., (2014) menggarisbawahi bahwa dengan menerapkan metode MFA dapat memahami jalur, stok, dan aliran material. Oleh karena itu, pengelolaan limbah elektronika dapat diasumsikan sebagai manajemen aliran material. Dalam konteks regional, konsep manajemen limbah elektronika yang strategis didasarkan pada keberadaan arus dan pemangku kepentingan yang berkontribusi pada sistem baik secara langsung maupun tidak langsung.

Volume laju timbulan limbah dan aliran bahan limbah elektronik tidak diketahui karena kurangnya informasi tentang jumlah dan aliran limbah tersebut. Dengan demikian, hal ini akan memberikan peluang bagi DKI Jakarta dan wilayah lain di Indonesia untuk mulai menangani masalah peningkatan volume limbah elektronika. Selain itu, terdapat potensi risiko yang harus ditanggung karena rendahnya pengelolaan limbah elekronika seperti kerusakan lingkungan, kerugian sosial, dan kesehatan manusia. Ruang lingkup penelitian ini lebih difokuskan pada beberapa jenis limbah elektronika yang mengandung senyawa PCBs seperti lemari es, AC, mesin cuci, dan televisi. Penelitian ini bertujuan untuk mengisi kesenjangan informasi terkait volume dan aliran material limbah elektronika untuk penyusunan rencana pengelolaan limbah berkelanjutan di DKI Jakarta.

\section{Metode Penelitian}

Penelitian ini dilakukan pada bulan April hingga Agustus 2018. Penelitian lapangan dilakukan di DKI Jakarta. Pemilihan lokasi ini ditentukan secara purposif dengan berbagai pertimbangan, seperti:

a. Pertumbuhan penduduk di DKI Jakarta yang meningkat secara signifikan yang berpotensi meningkatkan laju timbulan limbah elektronika

b. Tidak tersedianya data terkait volume sampah elektronik di rumah tangga dan sektor informal daur ulang sampah elektronik

c. Belum optimalnya pengelolaan limbah elektronika di DKI Jakarta dan secara umum di Indonesia.

Berdasarkan kenyataan bahwa data tentang laju timbulan limbah elektronika dan aliran limbah elektronik belum tersedia, maka metodologi yang digunakan terutama adalah akuisisi data dan analisis skema pembangkitan limbah elektronik oleh pembeli alat elektronik. Untuk membantu penghitungan limbah elektrnika menggunakan kuesioner yang ditujukan pada 
konsumen utama termasuk rumah tanggadan para pelaku sektor informal limbah elektronika seperti: pemulung, pengepul, jasa perbaikan barang elektronik. Studi lapangan dilakukan melalui kunjungan lapangan dan wawancara dengan informan kunci dengan pemangku kepentingan utama termasuk konsumen dan jasa perbaikan di lima kotamadya di DKI Jakarta.

Metode MFA terdiri dari beberapa variasi metode seperti yang disarankan oleh lembaga lingkungan Eropa untuk menganalisis tingkat potensial dari pembuangan limbah elektronika seperti metode time step, metode pasokan pasar, metode Carnegie Mellon, dan beberapa metode pendekatan lainnya (Babu et al. , 2007). Dalam studi ini, metode "penggunaan dan konsumsi" yang diadopsi dari penelitian Osibanjo dan Nnorom (2008) diterapkan untuk memperkirakan jumlah limbah elektronika di masyarakat. Perkiraan jumlah limbah elektronika diperoleh dengan mempertimbangkan tingkat persediaan peralatan elektronik rumah tangga. Selanjutnya, untuk mendapatkan jumlah limbah elektronika dilakukan dengan membagi total persediaan dibagi rata-rata usia penggunaan. Selain itu, tingkat persediaan mempertimbangkan jumlah anggota keluarga dalam rumah tangga. Berbagai catatan dalam penerapan metode ini termasuk jumlah rata-rata peralatan listrik dan elektronik di masyarakat dan usia penggunaan. Usia pakai produk adalah salah satu faktor penting dalam memperkirakan jumlah limbah elektronika. Ratarata usia pakai peralatan elektronik mengacu pada penelitian sebelumnya yang dilakukan oleh Oguchi et al., (2008).

\section{Hasil dan Pembahasan}

\subsection{Analisis Aliran Material}

Dari hasil survei yang telah dilakukan pada rumah tangga dan sektor informal dapat diketahui jenis dan jumlah barang elektronik yang kemudian digunakan sebagai dasar untuk menentukan potensi dari e-waste generation. Penghitungan ini bertujuan untuk menentukan estimasi tingkat potensi pembentukan e-waste di DKI Jakarta. Jenis barang elektronik atau produk yang dihitung adalah produk elektronik yang masih dalam kondisi baik dan produk elektronik yang ada di sektor informal. Selanjutnya, dengan menggunakan persamaan potensial untuk generasi e-waste (Chung et al., 2011) sebagai berikut:

$$
E=\frac{W \cdot N}{L}(1
$$

\section{Dimana:}

$\mathrm{E}=$ Potensi pembentukan e-waste $(\mathrm{Kg} /$ tahun $)$

$\mathrm{W}=$ Berat rata-rata dari setiap jenis produk elektronik (kg)

$\mathrm{N}=$ Jumlah unit produk elektronik per jenis

$\mathrm{L}=$ Umur rata-rata setiap jenis produk (tahun)
Misalnya, perhitungan untuk produk AC dengan ukuran $1 \mathrm{pk}$. Total jumlah AC 1pk dari rumah tangga sebanyak 222 unit dan dari sektor informal 130 unit. Jadi total AC 1pk adalah 352 unit. Dengan berat rata-rata AC $1 \mathrm{pk}$ sekitar 31.16kg. Dengan masa hidup sekitar 12,7 tahun. Dengan demikian perhitungan laju pembangkitan untuk AC $1 \mathrm{pk}$ adalah:

$$
\begin{gathered}
E=\frac{W \cdot N}{L} \\
E=\frac{(31.16) \cdot(352)}{12.7} \\
=863.65 \mathrm{Kg} / \text { tahun }
\end{gathered}
$$

Berdasarkan contoh di atas, dapat dilihat total berat limbah elektronika untuk semua produk yang ditunjukkan pada Tabel 1 .

Mengacu pada Tabel 1, dapat dilakukan perhitungan potensi rata-rata laju timbulan limbah elektronika untuk setiap orang. Ini perlu dilakukan untuk menentukan laju tingkat limbah elektronika di suatu area. Oleh karena itu, untuk mengetahui potensi rata-rata laju timbulan limbah elektronika di DKI Jakarta adalah sebagai berikut:

- Jumlah timbulan limbah elektronika dari hasil survei $=7713,42 \mathrm{~kg} /$ tahun

- Survei dilakukan terhadap 400 rumah tangga dan 54 sektor informal. Dari hasil kuesioner, jumlah total orang dalam keluarga adalah 1908 orang.

Dengan menggunakan formulasi di bawah ini, maka:

$$
\begin{gathered}
\text { Rata }- \text { rata limbah }=\frac{\text { Total limbah }}{\text { Total jumlah orang dalam rumah }} \\
\text { Rata }- \text { rata limbah }=\frac{7713,4201}{1908} \\
=4,04 \mathrm{Kg} / \text { Tahun }
\end{gathered}
$$

Dari hasil perhitungan di atas, potensi ewaste generation yang dihasilkan oleh setiap orang di Provinsi DKI Jakarta diperoleh sebesar $4,04 \mathrm{~kg} /$ tahun.

Analisis aliran material adalah model yang dapat menunjukkan hubungan antara lingkungan dan ekonomi serta dapat mengetahui dinamika yang terjadi dalam aliran material (Hinterberger et al. 2003). Bahan-bahan mentah yang diekstrak dari sistem alami kemudian diolah menjadi produk-produk tertentu yang kemudian direalisasikan dalam bentuk limbah dan sistem emisi.

Analisis aliran material dapat diterapkan dalam pengelolaan limbah sebagai kerangka kerja untuk pemodelan komposisi unsur limbah dan mengevaluasi pemberlakuan manajemen material di divisi daur ulang. Dengan demikian, analisis aliran material dapat menjadi alat pendukung keputusan yang menarik dalam manajemen 
sumber daya (Brunner dan Rechberger, 2004). Selanjutnya, Hinterberger dkk. (2003) juga menggarisbawahi bahwa limbah yang dihasilkan dari sistem adalah target tertinggi dalam analisis aliran material mengingat jumlah limbah yang terkumpul dapat menggambarkan siklus keluaran material yang tidak berkelanjutan dan menunjukkan perlunya remediasi sistem. Dengan demikian, analisis aliran material secara sistematis dapat dikaitkan dengan sumber, jalur dan pembuangan akhir dari suatu material (Brunner dan Rechberger, 2004; Steubing et al.,
2010). Beberapa penelitian telah dilakukan menggunakan metode analisis aliran material untuk mengukur dan menyimpulkan aliran jenis e-waste yang terjamin (Kang dan Schoenung, 2006; Kumar dan Shrihari, 2007; Steubing et al., 2010). Selain itu, metode analisis aliran material juga diimplementasikan untuk mengidentifikasi rantai yang menghubungkan berbagai fase siklus hidup e-waste dan pemangku kepentingan terkait (Streicher-Porte et al., 2005; Jain dan Sareen, 2006).

Tabel 1.Perhitungan potensi tingkat laju timbulan limbah elektronika untuk semua produk

\begin{tabular}{|c|c|c|c|c|c|c|}
\hline \multirow[t]{2}{*}{ No } & \multirow[t]{2}{*}{ Jenis Produk } & $\begin{array}{l}\text { Berat } \\
\text { (kg) }\end{array}$ & $\begin{array}{l}\text { Jumlah } \\
\text { (unit) }\end{array}$ & $\begin{array}{l}\text { Rata-rata usia } \\
\text { pakai (tahun) }\end{array}$ & $\begin{array}{l}\text { Total berat } \\
\text { (kg) }\end{array}$ & $\begin{array}{c}\text { Potensi Laju timbulan } \\
\text { (kg/tahun) }\end{array}$ \\
\hline & & A & B & $\mathrm{C}$ & $(\mathrm{AxB})$ & $(\mathrm{AxB}) / \mathrm{C}$ \\
\hline 1 & 1 door refrigerator & 31,82 & 242 & 11,8 & 7700,44 & 652,579661 \\
\hline 2 & 2 door refrigerator & 65,6 & 304 & 11,8 & 19942,4 & 1690,0339 \\
\hline 3 & Refrigerator side by side door & 102 & 49 & 11,8 & 4998 & 423,559322 \\
\hline 4 & AC $1 / 2 \mathrm{PK}$ & 26,8 & 387 & 12,7 & 10371,6 & 816,661417 \\
\hline 5 & AC 1 PK & 31,16 & 352 & 12,7 & 10968,32 & 863,647244 \\
\hline 6 & 2 tube washing machine & 67,5 & 258 & 10,1 & 17415 & 1724,25743 \\
\hline 7 & Top load washing machine & 27,25 & 113 & 10,1 & 3079,25 & 304,876238 \\
\hline 8 & Front load washing machine & 41,5 & 62 & 10,1 & 2573 & 254,752475 \\
\hline 9 & TV LED 17" & 6,5 & 53 & 22,5 & 344,5 & 15,3111111 \\
\hline 10 & TV LED 19" & 7 & 47 & 22,5 & 329 & 14,6222222 \\
\hline 11 & TV LED 21" & 7,5 & 60 & 22,5 & 450 & 20 \\
\hline 12 & TV LED 24" & 9 & 61 & 22,5 & 549 & 24,4 \\
\hline 13 & TV LED 32" & 13,5 & 172 & 22,5 & 2322 & 103,2 \\
\hline 14 & TV LED 40" & 16,66 & 39 & 22,5 & 649,74 & 28,8773333 \\
\hline 15 & TV LED 42" & 10,1 & 52 & 22,5 & 525,2 & 23,3422222 \\
\hline 16 & TV LED 43" & 11,8 & 30 & 22,5 & 354 & 15,7333333 \\
\hline 17 & TV LED 45" & 11,5 & 46 & 22,5 & 529 & 23,5111111 \\
\hline 18 & TV LED 49" & 5,5 & 33 & 22,5 & 181,5 & 8,06666667 \\
\hline 19 & TV LCD 17" & 5,5 & 46 & 22,5 & 253 & 11,2444444 \\
\hline 20 & TV LCD 19" & 7,6 & 44 & 22,5 & 334,4 & 14,8622222 \\
\hline 21 & TV LCD 21" & 5,1 & 68 & 22,5 & 346,8 & 15,4133333 \\
\hline 22 & TV LCD 24" & 4,6 & 86 & 22,5 & 395,6 & 17,5822222 \\
\hline 23 & TV LCD 32" & 10,5 & 169 & 22,5 & 1774,5 & 78,8666667 \\
\hline 24 & TV LCD 40" & 6,9 & 44 & 22,5 & 303,6 & 13,4933333 \\
\hline 25 & TV LCD 42" & 13,5 & 46 & 22,5 & 621 & 27,6 \\
\hline 26 & TV LCD 43" & 14,8 & 43 & 22,5 & 636,4 & 28,2844444 \\
\hline 27 & TV LCD 45" & 12,5 & 59 & 22,5 & 737,5 & 32,7777778 \\
\hline 28 & TV LCD 49" & 13,4 & 44 & 22,5 & 589,6 & 26,2044444 \\
\hline 29 & TV CRT 14" & 9,34 & 142 & 22,5 & 1326,28 & 58,9457778 \\
\hline 30 & TV CRT 21" & 20,47 & 148 & 22,5 & 3029,56 & 134,647111 \\
\hline 31 & TV CRT 29" & 39 & 106 & 22,5 & 4134 & 183,733333 \\
\hline 32 & TV Plasma 42" & 15 & 28 & 22,5 & 420 & 18,6666667 \\
\hline 33 & TV Plasma 43" & 15 & 16 & 22,5 & 240 & 10,6666667 \\
\hline 34 & TV Plasma 50" & 22,5 & 15 & 22,5 & 337,5 & 15 \\
\hline 35 & TV Plasma 51" & 22,5 & 18 & 22,5 & 405 & 18 \\
\hline & & Total & & & & 7713,42013 \\
\hline
\end{tabular}




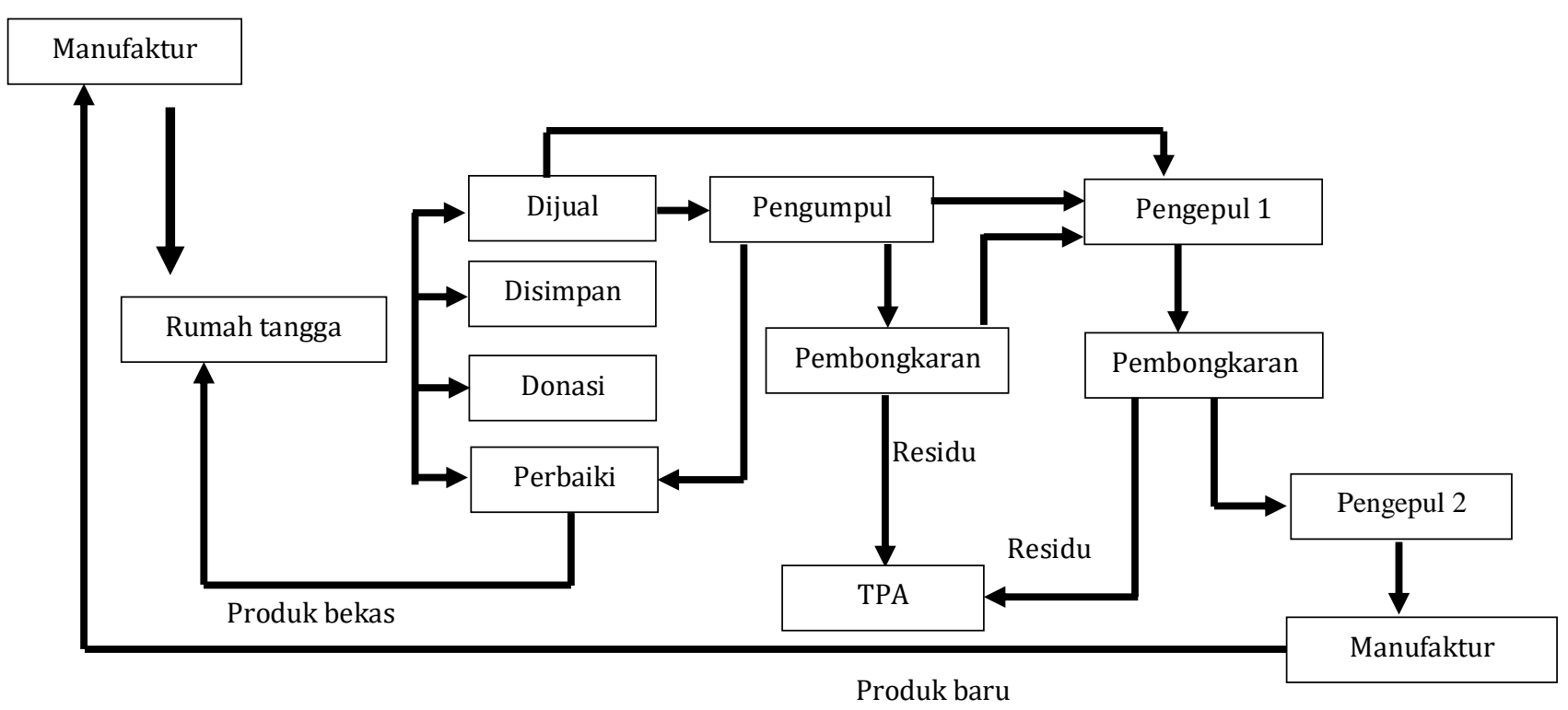

Gambar 1.Peta aliran limbah elektronika di DKI Jakarta

Berdasarkan hasil perhitungan yang telah dilakukan sebelumnya dapat dilakukan pembuatan aliran limbah elektronika dari rumah tangga ke TPA. Rute aliran limbah elektronika umumnya dimulai dengan produk yang diproduksi oleh manufaktur. Produk elektronik yang memiliki masa hidup akan menjadi tidak berfungsi atau fungsinya telah mulai menyusut dan menjadi limbah. Limbah elektronikaadalah alat atau peralatan rumah tangga dari elektronik yang tidak berfungsi dengan baik dan tidak lagi digunakan oleh konsumen. Di beberapa negara berkembang, produk yang tidak berfungsiakan diperbaiki, diproses ulang atau dibuang. Jalur produk elektronik untuk menentukan aliran limbah elektronikayang terjadi di DKI Jakarta seperti yang ditunjukkan pada Gambar 1 .

Peralatan elektronik yang kondisinya tidak lagi digunakan memiliki perlakuan yang berbeda. Menurut survei yang dilakukan pada 400 rumah tangga diperoleh informasi bahwa masyarakat memiliki cara yang tidak sama dalam memperlakukan produk elektronik yang tidak lagi berfungsi. Sebagai contoh, beberapa responden mengatakan bahwa mereka akan membawa produk tersebut ke jasa perbaikan. Selain itu, ada juga responden yang disimpan untuk alasan tertentu atau menyumbang peralatan elektronik kepada orang lain dan banyak yang menjual produk elektronik kepada kolektor atau pengumpul produk bekas.

Kondisi produk elektronik yang dijual kepada pemetik atau kolektor memiliki karakteristik tersendiri. Dari survei lapangan, diperoleh informasi bahwa beberapa produk tidak dapat berfungsi sama sekali atau rusak dan yang lain masih bisa berfungsi. Selain itu, berdasarkan survei diperoleh informasi bahwa ada beberapa pihak yang memiliki peran penting dalam pengelolaan limbah elektronik, seperti pekerja layanan, pemetik, pengepul dan pabrik.

a. Jasa perbaikan produk elektronik memiliki peran dalam aliran material limbah elektronika di DKI Jakarta. Umumnya, mereka menggunakan keterampilan dan pengetahuan yang mereka miliki dalam hal meningkatkan produk elektronik. Dari survei yang telah dilakukan, diperoleh informasi bahwa perbaikan produk elektronik menerima barang dari masyarakat. Masyarakat menggunakan layanan perbaikan untuk memperpanjang masa pakai produk yang mereka miliki. Untuk produk yang berfungsi, mereka akan diperbaiki agar dapat digunakan dan dijual kembali kepada konsumen. Reparasi produk elektronik juga mengambil bagian dalam komponen dari produk elektronik yang telah rusak dan akan digunakan dalam produk serupa. Selain itu, jasa perbaikan juga akan datang ke kolektor untuk mencari komponen elektronik sebagai pilihan kedua jika harga komponen ini mahal. Berdasarkan hasil survei dan wawancara diperoleh informasi bahwa produk elektronik yang telah diperbaiki juga dijual kembali ke publik dengan harga yang sesuai dengan kondisi produk tersebut.

b. Pihak pertama yang mengelola limbah elektronika adalah pengumpul. Para pengumpul ini biasanya bekerja dengan mencari produk dari rumah ke rumah. Setelah mengumpulkan produk elektronik, pemeriksaan dilakukan 
mengenai kondisi produk. Jika kondisinya masih dalam kondisi baik, ia akan dipisahkan dan dikumpulkan untuk dijual kepada jasa perbaikan atau kolektor yang menerima barang elektronik. Selain itu, produk elektronik yang kondisinya benarbenar rusak akan dibongkar untuk mengambil komponen yang masih berfungsi atau mengambil material lain yang masih memiliki nilai ekonomis. Misalnya, kaca di televisi yang akan dibongkar dan dipisahkan kemudian akan dijual kepada para kolektor. Begitu juga untuk kabel dalam produk elektronik yang hanya akan digunakan untuk tembaga atau logam kuningan. Tidak semua produk dijual ke pengepul karena ada beberapa yang tidak memiliki nilai jual sama sekali sehingga menjadi residu dan dibuang di TPA.

c. Para pengepul juga merupakan salah satu aktor dalam pengelolaan limbah elektronika yang memegang peranan yang sangat signifikan. Mereka menerima produk elektronik yang telah rusak baik langsung dari masyarakat maupun dari para pengumpul. Secara umum, perlakuan produk elektronik pada pengumpul tidak jauh berbeda dengan apa yang dilakukan pada pemetik. Mereka akan membongkar produk elektronik ini untuk mengambil bahan yang masih memiliki nilai jual. Selain itu, tidak semua material memiliki nilai ekonomi dan dapat dijual pada tingkat pengepul besar. Bahan yang tidak memiliki nilai jual akan dibuang di tempat sampah dan kemudian akan dibawa ke TPA.

d. Pihak terakhir yang juga berperan dalam pengelolaan limbah elektronika adalah pabrik. Pabrik ini akan menerima material-material yang akan dilebur menjadi bahan baku lagi dan dijual ke produsen untuk diolah menjadi komponen produk elektronik. Misalnya, body produk elektronik terbuat dari plastik dan diperoleh dari pengepul akan digabung dengan jenis plastik yang sama dan kemudian diolah menjadi biji plastik. Selanjutnya, biji plastik akan dijual ke pabrik lainnya untuk dicetak menjadi produk baru.

Berdasarkan uraian tersebut dilakukan analisis lebih lanjut tentang aliran material. Pada prinsipnya, metode analisis aliran massa digunakan untuk menentukan aliran material dari produksi untuk dibuang ke lingkungan (Oguchi et al., 2008). Namun, dalam penelitian ini hanya terbatas atau dihitung aliran bahan untuk produk elektronik dari rumah tangga ke tempat pembuangan akhir. Selanjutnya, dari hasil survei 125 dan wawancara yang telah dilakukan, analisis aliran massa produk elektronik akan ditunjukkan pada Gambar 1.

Dari Gambar 1 memberikan informasi tentang Analisis Aliran Massa limbah elektronika dari rumah tangga hingga berakhir di TPA. Limbahelektronika yang diperoleh dari rumah tangga sekitar 7713,42 kg/tahun. Selanjutnya, rumah tangga yang memperlakukan limbah tersebut ke jasa perbaikan, kemudian menjual ke pengumpul dan pengepul tingkat pertama. Persentase limbah elektronika yang dibawa ke pengepul tingkat pertama kira-kira $18 \%$ atau sekitar 1388,416 kg/tahun. Selain itu, yang dijual ke pengumpul sekitar 67\% atau $5167 \mathrm{~kg} /$ tahun.

Selanjutnya, produk elektronika juga mengalami perbaikan di reparasi elektronik. Jasa perbaikan juga mendapatkan limbah elektronika dari pengumpul sekitar 15\%. Jadi, total limbah elektronika di tukang reparasi sekitar 1932.211 $\mathrm{kg} /$ tahun. Reparasi produk elektronik membeli limbah elektronika dari pengepul untuk mendapatkan komponen yang masih berfungsi dan biasanya digunakan untuk mengganti komponen yang rusak dalam produk yang diperbaiki. Selain itu, tukang reparasi juga menjual produk elektronik yang telah diperbaiki dan berfungsi lagi di masyarakat dengan harga yang lebih murah dan disesuaikan dengan kondisi produknya.

Terdapat dua kegiatan yang dilakukan oleh pengepul tingkat pertama limbah elektronika, yaitu membongkar produk elektronik untuk mendapatkan komponen elektronik yang masih berfungsi dan mencari bahan yang masih memiliki nilai ekonomi seperti kaca, plastik, dan logam. Selain itu, pengepul tingkat pertama juga hanya mencari dan mengumpulkan produk elektronik yang rusak atau digunakan dari masyarakat dan langsung menjual ke pengepul tingkat pertama. Dari hasil survei diperoleh informasi bahwa pengumpul yang langsung menjual ke pengepul pertama sebesar 75\%. Sementara itu, pengepul tingkat pertama membongkar untuk mendapatkan material yang memiliki nilai ekonomi sekitar 10\%. Dari hasil ini, bahan yang tidak lagi digunakan atau tidak memiliki nilai ekonomi atau residu sekitar 5\% diperoleh. Residu ini akan dibuang di TPA dan dicampur dengan limbah padat lainnya dari rumah tangga. Proses pembongkaran pada tingkat kolektor secara umum masih menggunakan teknologi sederhana dan memiliki potensi untuk mengurangi kualitas lingkungan dan kesehatan manusia.

Pada pengepul tingkat pertama didapatkan keterangan bahwa mereka juga mendapatkan produk elektronika rusak atau bekas dari masyarakat sekitar 18\%. Sebagaimana yang diuraikan sebelumnya bahwa para pengepul tingkat pertama juga menerima produk elektronika rusak atau bekas dari para pengumpul. Sehingga, total limbah elektronika 
yang diterima sebanyak 5264,42 kg/tahun dengan kandungan senyawa PCBs sekitar 0,0789 kg. Para tingkat pertama juga melakukan proses pembongkaran untuk memilah-milah guna memperoleh material yang berharga. Proses pembongkaran yang ada di level ini sekitar 95\% dan hanya sekitar $5 \%$ yang menjadi residu. Residu ini juga akan dibuang ke tempat pembuangan sampah dan bercampur dengan limbah padat lainnya dari rumah tangga. Hasil dari pembongkaran selanjutnya dijual ke para pengepul yang lebih besar (pengepul tingkat kedua).

Para pengepul tingkat kedua ini secara umum sudah mendapatkan limbah elektronika yang telah dipilah-pilah berdasarkan karakteristik materialnya karena pada level sebelumnya sudah tidak dicampur lagi. Pada pengepul tingkat kedua tersebut memperoleh material dalam limbah elektronika dari dua sumber yaitu pengumpul dan para pengepul. Sehingga total material dari limbah elektronika yang ditampung oleh mereka adalah sebesar 5497, $168 \mathrm{~kg} /$ tahun dengan kandungan senyawa PCBs sekitar 0,0824 kg. Selanjutnya material tersebut dijual ke pabrik yang membutuhkan.

Total residu dari limbah elektronika yang masuk ke tempat pembuangan sampah adalah sebesar 282, $89 \mathrm{~kg} /$ tahun dengan kandungan senyawa PCBs sekitar 0,0042 kg. Dengan demikian apabila ditambahkan dengan massa yang dijual ke pabrik (5497, $168 \mathrm{~kg} /$ tahun) dan ditambahkan dengan massa limbah elektronika yang ada di tukang servis (1932,211 kg/tahun) maka hasilnya akan seimbang dengan yang ada di rumah tangga.

Beberapa penelitian terkait penerapan metode MFA khususnya pada pengelolaan limbah elektronika telah banyak dipublikasikan. Sebagai contoh, penelitian oleh Morf dan Taverna (2004) melacak aliran material di negara Swiss, dimana dalam studinya belum mempertimbangkan keberadaan logam mulia. Lebih lanjut, penelitian tersebut hanya difokuskan pada logam dasar dan logam berat, klorin, potasium, polychlorinated biphenyl dan brominated retardants. Sementara itu, dampak dari aliran material menjadi fokus penelitian oleh Hischier dan rekan (2005). Penelusuran aliran material dari daur ulang komputer pribadi di negara India diungkap oleh Streicher-Porte et al., (2005). Tasaki et al., (2004) menitikberatkan penelitiannya pada aliran brominated flame retardants di Jepang. Studi tentang aliran material tembaga pada pengelolaan limbah dilakukan di Eropa (Bertram et al., 2002). Huisman (2004) menganalisis kinerja lingkungan berdasarkan skenario daur ulang yang berbeda dari beberapa limbah produk elektronika.

Sementara itu, proses aliran material limbah elektronika terutama monitor CRT menjadi perhatian Zumbuehl (2006). Dalam studinya dilakukan pemetaan rantai nilai CRT pada tiap-tiap stakeholder yang memegang peranan kunci aliran massa monitor CRT dan televisi. Selain itu, Ledwaba dan Sosibo (2016) menggarisbawahi bahwa secara umum aliran material CRT berawal dari konsumen yang membeli dari distributor lokal. Lebih lanjut, beberapa konsumen juga membeli komputer bekas yang telah diperbarui dari pemasok yang mengimpor untuk kebutuhan pasar sekunder. Setelah produk melewati usia pakai maka aliran material akan masuk ke para pengumpul yang membongkar limbah elektronika untuk pemisahan komponen. Setelah pemisahan, aliran material akan berlanjut ke lokasi penjualan komponen dan pabrik. Sedangkan aliran material yang tidak bernilai akan berujung di tempat pembuangan sampah Ledwaba dan Sosibo (2016). Estimasi dan perhitungan dari pembuangan limbah elektronika diperlukan dalam rangka mencari rencana dan strategi pengelolaan limbah elektronika yang tepat di Nigeria (Ibrahim et al. 2013). Dalam penelitian tersebut mengembangkan metode MFA yang didasarkan pada model data penjualan dari distributor komputer. Data lain yang digunakan adalah waktu penggunaan, koefisiensi transfer dari satu tahap ke tahapan lainnya. Selanjutnya, analisis MFA tersebut memperoleh informasi bahwa limbah komputer yang masih disimpan adalah sebesar 41\%, penggunaan kembali 35\% dan pembuangan sekitar $24 \%$. Selain itu, proyeksi pembuangan limbah komputer juga dilakukan untuk 15 tahun mendatang guna memperoleh gambaran tentang arus aliran material limbah komputer. Dari hasil proyeksi tersebut diperoleh bahwa aktivitas penyimpanan limbah oleh masyarakat memberikan dampak bagi pemerintah Nigeria untuk membuat dan mengembangkan rencana guna mengakomodir dan mengelola limbah yang dihasilkan (Ibrahim et al. 2013).

Aliran material dari produk PC baik CRT dan LCD di kota Santiago Chile terdiri dari beberapa tahapan, mulai dari rumah tangga, tukang servis, pemulung, pengepul dan berakhir di pabrik (Steubing et al., 2010). Dalam studi tersebut menggunakan wawancara pada pemilik toko komputer bekas. Keberadaan sektor informal yang terkait dengan aktivitas daur ulang limbah komputer sangat signifikan. Lebih lanjut, kebanyakan rumah tangga membeli komputer bekas dari toko atau jasa tukang servis. Sebagai akibatnya, penghasil limbah komputer terbesar adalah rumah tangga. Sehingga, diperlukan skema pengembalian yang lebih baik agar menjadi solusi bagi rumah tangga dan sektor informal dalam membuang dan mendaur ulang komputer yang sudah tidak berfungsi lagi. Selain itu, untuk dapat mengurangi risiko lingkungan dan kesehatan kerja dari proses daur ulang perlu adanya regulasi yang mengadopsi standar yang lebih baik (Steubing et al., 2010). 
Penelitian yang dilakukan oleh Shinkum dan Nguyen Thi Minh (2009) mencatat perangkat elektronika bekas dari jepang banyak digunakan di negara Vietnam dan Kamboja. Selain itu, proses daur ulang limbah elektronika dilakukan di Gangdong Cina. Dalam proses daur ulangnya masih belum menggunakan teknologi yang ramah lingkungan. Selanjutnya, prosentase komputer pribadi yang dibuang ke pembuangan domestik dan daur ulang di jepang mengalami penurunan menjadi $37 \%$, sedangkan proporsi penggunaan kembali dan ekspor mengalami peningkatan (Yoshida et al. 2009). Lebih lanjut, Jain dan Sareen (2006) mengaplikasikan metode MFA dengan menggunakan metode pasokan pasar, dimana metode ini menggunakan data yang dihasilkan dari produsen produk elektronika baik produksi maupun penjualan. Metode survei untuk memperkirakan jumlah dan aliran limbah elektronika digunakan oleh (Osibanjo dan Nnorom, 2008) dimana volume limbah elektronika yang dihasilkan mengalami peningkatan di beberapa negara seperti Cina, India, Nigeria dan Chile. Penggunaan metode MFA dan evaluasi nilai ekonomi sebagai alat analisis pada limbah komputer di India (Streicher-Porte, 2007). Dalam studi tersebut dikemukakan bahwa konsentrasi $\mathrm{Au}$ dan $\mathrm{Cu}$ mempunyai nilai ekonomis yang tinggi dan menghasilkan keuntungan bagi sektor informal daur ulang limbah elektronika. Lebih lanjut, melalui penggabungan metode MFA dan evaluasi ekonomi dapat menjadi alat analisis yang sangat berguna apabila terdapat keterbatasan data.

Selain itu, studi yang dilakukan oleh Astuti dkk., (2012) menunjukkan sebagian besar perilaku masyarakat di Kota Semarang dalam memperlakukan produk elektronika setelah tidak digunakan dengan membawa produk tersebut ke tukan servis elektronika. Lebih lanjut, studi tersebut juga mengindentifikasi kontribusi jasa servis elektronika dalam proses daur ulang limbah elektronika secara informal. Berdasarkan hasil kajian dalam studi tersebut menunjukkan sebaran lokasi tukan servis di lima wilayah di kota Semarang.

\subsection{Usulan strategi sistem manajemen limbah elektronika berkelanjutan di DKI Jakarta}

Sistem manajemen limbah elektronik yang berkelanjutan adalah suatu keharusan yang harus dilakukan untuk mengurangi potensi risiko kerusakan lingkungan dan kesehatan manusia menurun. Ini harus mempertimbangkan berbagai faktor seperti volume, dan jenis produk elektronik, penjualan saat ini produk elektronik, praktek daur ulang di sektor formal dan informal, peraturan pemerintah, aliran limbah elektronika, jenis pemrosesan limbah elektronika, praktik sosial dan budaya masyarakat, para pemangku kepentingan bertanggung jawab. a. Pendekatan Extended Producer Responsibility (EPR) dapat diusulkan dalam sistem pengelolaan limbah elektronik di DKI Jakarta. Ada beberapa tujuan dari penerapan EPR seperti meminimalkan volume limbah elektronika, mengurangi pembuangan, mengurangi senyawa berbahaya dalam limbah elektronika, mengurangi penggunaan material asli, meminimalkan polusi dan meningkatkan kualitas lingkungan. Program ini dapat menjadi salah satu strategi dalam mengatasi aliran material karena peranan industry manufaktur produk elektronika lebih diberi kewenangan. Pelaksanaan program EPR telah banyak dilakukan di negaranegara Asia dan Eropa seperti Jepang, Korea, Taiwan, Swiss. Penerapan biaya transportasi dan daur ulang dilakukan oleh orang-orang yang membuang limbah elektronik di Jepang. Selain itu, produsen membayar biaya daur ulang di Korea dan Taiwan. Selanjutnya, organisasi gabungan ini dibentuk oleh produsen untuk mengelola limbah elektronika dan pengolahannya didistribusikan di sektor formal yang memiliki lisensi di Swiss.

Selain itu, peraturan yang mengatur EPR di negara maju telah dianggap serius. Namun, peraturan yang ada di Indonesia tidak secara khusus mengatur pengelolaan limbah elektronik. Misalnya, Peraturan Pemerintah Indonesia No. 81 tahun 2012 sebagai turunan dari UU No. 18 tahun 2008 hanya mengatur pengelolaan limbah dari rumah tangga dan tidak mencakup limbah elektronik. Dalam peraturan ini, pabrikan harus menarik (mengambil kembali) sampah untuk didaur ulang secara bertahap. Selain itu, pengaturan dan pengelolaan limbah elektronik masih mengacu pada peraturan yang mengatur limbah berbahaya dan beracun seperti UU No. 32 tahun 2009 tentang Perlindungan dan Pengelolaan Lingkungan; PP No. 101 tahun 2014 tentang Pengelolaan Sampah B3. Namun, semua peraturan ini hanya mengatur secara umum dan tidak secara spesifik menentukan definisi, kriteria, dan aliran pengelolaan limbah elektronik.

Perumusan program EPR harus mencakup perumusan sistem manajemen pengumpulan limbah elektronik, mengambil kembali sistem dengan memberikan insentif untuk meningkatkan kesadaran publik, sistem kemitraan publik swasta seperti menyediakan titik pengumpulan di supermarket untuk pengumpulan, menyediakan teknologi yang ramah lingkungan ke industri 
pengolahan limbah elektronik, skema subsidi dari pemerintah, dan sumber pendanaan lainnya. Perumusan EPR juga perlu mengintegrasikan sektor informal sebagai pemain yang ada misalnya sebagai bagian dari kegiatan pengumpulan sampah dari sektor rumah tangga. Namun, ada kemungkinan bahwa sektor informal yang telah memenuhi persyaratan tertentu dapat diformalkan sesuai dengan peraturan yang berlaku.

b. Selain program EPR, strategi lainnya yang dapat dilaksanakan adalah dengan mengembangkan program pengumpulan melalui Dropbox.Melalui strategi ini diharapkan dapat memperbaiki aliran limbah material terutama dalam kaitannya dengan proses pengumpulan, pewadahan dan proses pemindahan (transfer). Dropbox ditempatkan di berbagai lokasi untuk mengumpulkan limbah elektronik dari masyarakat. Penempatan Dropbox juga membutuhkan petugas atau relawan yang dapat memberikan penjelasan kepada masyarakat. Penempatan Dropbox harus dilakukan di lembaga pendidikan dan lembaga pemerintah. Penempatan Dropbox tanpa petugas atau sukarelawan apa pun tidak dapat berjalan efektif untuk mendorong partisipasi masyarakat. Selanjutnya, pembuatan dropbox dapat dilakukan oleh produsen, agen penjualan produk elektronikaatau pihak yang terkait dengan manajemen limbah elektronik.

\section{Kesimpulan}

Kesimpulannya, penelitian ini bertujuan untuk menjelaskan masalah manajemen limbah elektronik di Jakarta. Masalah pengelolaan limbah elektronik tidak hanya terjadi di negara-negara maju tetapi juga di negara-negara berkembang. Perubahan dalam inovasi teknologi mendorong produk elektronik dengan cepat ketinggalan zaman dan meningkatkan volume limbah elektronik. Penelitian ini juga menunjukkan bahwa total limbah elektronik yang dihasilkan adalah $7713.42013 \mathrm{~kg} /$ tahun. Selain itu, aliran material menunjukkan bahwa ada beberapa pemangku kepentingan kunci dalam pengelolaan limbah elektronik di DKI Jakarta seperti, pengumpul, pengepul tingkat pertama, pengepul tingkat kedua dan pabrik. Beberapa usulan strategi dapat dilakukan untuk meningkatkan pengelolaan limbah elektronik yang berkelanjutan. Selanjutnya, penelitian ini dapat menjadi pemicu untuk penelitian selanjutnya karena masih ada beberapa kekurangan.

\section{Ucapan terima kasih}

Saya ingin mengucapkan terima kasih kepada Kementerian Keuangan dan Riset dan Teknologi DIKTI yang menyediakan pendanaan melalui beasiswa BUDI-LPDP 2016.

\section{DAFTAR PUSTAKA}

Astuti W., Purwanto, Damanhuri E., 2012, Studi Persepsi Dan Perilaku Jasa Servis Dalam Memperpanjang Aliran Limbah Elektronik (E Waste) Di Kota Semarang, Prosiding Seminar Nasional Pengelolaan Sumberdaya Alam dan Lingkungan, Semarang, 11 September 2012, Terdapat pada: http://eprints.undip.ac.id/37632/1/02Widi_Astuti.pdf(Diakses: 01 Mei 2019)

Babu, B.R., ParandeA.K., and Basha C.A. 2007. Electrical and e-waste: A global environmental problem. Waste Manage. Res. 25:307-318. doi:10.1177/0734242x07076941

Bertram, M., Graedel, T.E., Rechberger,H., and Spatari, S. 2002. The contemporary European copper cycle: waste management subsystem, Ecol Econ 42, pp. 43-57.

Brunner. P.H., Rechberger, H. 2004. Practical Handbook of Material Flow Analysis, Boca Raton(EN): Lewis Publishers.

Chung, S., Lau, K., Zhang, C. 2011. Generation of and control measures for e-waste in Hong Kong. Waste Manag. 31 (3), 544-554.

Duygan, M., Meylan, G. 2015. Strategic management of WEEE in Switzerland-combining material flow analysis with structural analysis. Resour. Conserv. Recycl. 103, 98-109.

Hinterberger, F., S. Giljum, and Hammer M., 2003. Material Flow Accounting and Analysis (MFA). A valuable tool for analyses of Society-Nature interrelationships. Sustainable Europe Research Institute (SERI) Background Paper, Nr. 2, August 2003

Hischier, R, Wager, P, Gauglhofer J. 2005. Does WEEE recycling make sense from an environmental perspective? The environmental impacts of the Swiss take-back and recycling systems for waste electrical and electronic equipment (WEEE). Environmental Impact Assessment Review. 25(5): 525-539.

Huisman, J., \&Stevels, A. 2004. Eco-efficient implementation of electronic waste policies in practice.Electronics and the Environment Conference Record for 2004 IEEE International Symposium, pp. 243-248.

Ibrahim,F.B., Adie, D.B, Giwa,A., Abdullahi,S.A., Okuofu, C.A. 2013, Material Flow Analysis of Electronic Wastes (e-Wastes) in Lagos, Nigeria, Journal of Environmental Protection, 4, 1011-1017

Jain, A, Sareen, R. 2006. E-waste assessment methodology and validation in India, J Mater Cycles Waste Manag. 8: 40-45 https://doi.org/10.1007/s10163-005-0145-2

Kalmykova, Y., Patricio, J., Rosado, L., Berg, P.E. 2015. Out with the old, out with the new-the effect of transitions in TVs and monitors technology on consumption and WEEE generation in Sweden 1996-2014. Waste Manage. 46, 511-522.

Kang, H.Y., Schoenung, J.M. 2006. "Estimation of Future Outflows and Infrastructure Needed to Recycle Personal Computer Systems in California," Journal of Hazardous Materials, Vol. 137, No. 2, pp. 1165- 
1174.

http://dx.doi.org/10.1016/i.jhazmat.2006.03.062

Kiddee, P., Naidu R., Wong M.H.2013, E-waste management approaches: An overview, Waste Management 33,1237-1250

Kumar, P., Shrihari, S. 2007. Estimation and Material Flow Analysis of Waste Electrical and Electronic Equipment (WEEE) - A Case Study of Mangalore City, Karnataka, India Proceedings of the International Conference on Sustainable Solid Waste Management. Chennai, India (EN). pp. 148154. Available at: http://citeseerx.ist.psu.edu/viewdoc/download?d oi=10.1.1.551.8067\&rep=rep1\&type=pdf

Ledwaba,P., and Sosibo, N. 2017, Cathode Ray Tube Recycling in South Africa, Recycling, 2, 4; doi:10.3390/recycling2010004

Muller, E., Hilty, L.M., Widmer, R., Schluep, M., Faulstich, M. 2014. Modeling metal stocks and flows: a review of dynamic material flow analysis methods. Environ. Sci. Technol. 48, 2102-2113.

Nnorom, I.C. and O. Osibanjo, 2008. E-waste (e-waste): Material flows and management practices in Nigeria. Waste Management, 28(8): p. 1472-1479.

Oguchi, M., Kameya T., Yagi, S., and Urano ,K. 2008, Product flow analysis of various consumer durables in Japan, Resources, Conservation and Recycling, Vol. 52, pp. 463-480.

Shah, M.A., Batool R. 2015.An Overview of E-waste Management, Practices and Impending Challenges, International Journal of Computer Applications, Volume 125 - No.2, (0975 - 8887)

Schluep, M., Hagelüken, C., Kuehr, R., Magalini, F., Maurer, C., Meskers, C., Muellera, E., Wang, F. 2009. Sustainable innovation \& technology transfer industrial sector studies: recyclingefrom e-waste to resources. United Nations Environment Programme (UNEP) and StEPesolving the e-waste problem. 2009. Available at: http://www.unep.org/pdf/Recycling_From_ewaste_to_resources.pdf. Diakses pada 14 Oktober 2017

Sepulveda, A., Schluep, M., Renaud, F.G., Streicher, M., Kuehr, R., Hageluken, C., Gerecke, A.C. 2010. A review of the environmental fate and effects of hazardous substances released from electrical and electronic equipments during recycling: Examples from China and India. Environmental Impact Assessment Review. 30: 28-41

Sinha, S. 2010.Sustainable E-waste Management, Diakses pada 22 Agustus2018,terdapat pada: www.toxicslink.org/artview.php?id=134

Steubing, B., Böni, H., Schluep, M., Silva, U. and Ludwig, C. 2010. Assessing computer waste generation in Chile using material flow analysis, Waste Management, Vol. 30, pp. 473-482.

Streicher-Porte, M., Widmer, R., Jain, A., Bader, H.P., Scheidegger, R. and Kytzia, S. 2005. Key drivers of the e-waste recycling system: Assessing and modelling e-waste processing in the informal sector in Delhi, Environmental Impact Assessment Review, Vol. 25, pp. 472-491.

Terazono, A.,Murakami, S., Abe, N., Inanc, B., Moriguchi, Y., Sakai, S., Kojima, M., Yoshida, A., Li, J., Yang, J., Wong, M.H., Jain, A., Kim, I., Peralta, G.L., Lin, C., Mungcharoen, T., Williams, E. 2006. Current status and research on E-waste issues in Asia, J Mater Cycles Waste Manag. 8:1-12, DOI 10.1007/s10163-005-0147-0

United Nation Environment Programme (UNEP), 2006, Secretariat of the Basel Convention, Geneva, Switzerland, Terdapat pada: www.basel.int. (diakses pada 01 April 2016)

Yang, J.X., Xu, C., Liu, X.L. 2004. E-waste issues and measures in China. In: Proceedings of The Third Workshop on Material Cycles and Waste Management in Asia (NIES E-waste Workshop), December 14-15, NIES, Tsukuba, Japan

Yoshida, A., T. Tasaki, and A. Terazono. 2009. Material flow analysis of used personal computers in Japan. Waste Management, 29(5): p. 1602-1614.

Zeng, X., Gong, R., Chen, W.Q., Li, J. 2015. Uncovering the recycling potential of 'new' WEEE in China. Environ. Sci. Technol.

Zoeteman,B.C.J., Krikke, H.R., Venselaar, J. 2010. Handling WEEE waste flows: on the effectiveness of producer responsibility in a globalizing world. Int J AdvManufTechnol; 47:415-36.

Zumbuehl, D. 2006. Mass flow assessment (MFA) and assessment of recycling strategies for cathode ray tubes (CRTs) for the Cape Metropolitan Area (CMA), South Africa. Diploma thesis at ETH Zurich. 